\title{
New Data About Breeding of the Cinereous Vulture in the Republic of Altail, Russia
}

\section{НОВЫЕ ДАННЫЕ О ГНЕЗДЯЩИХСЯ ЧЁРНЫХ ГРИФАХ В РЕСПУБЛИКЕ АЛТАЙ, РОССИЯ}

\author{
Shnayder E.P. (LLC Sibecocenter, Berdsk, Novosibirsk region, Russia) \\ Шнайдер Е.П. (ООО «Сибэкоцентр», Бердск, Новосибирская область, Россия)
}

DOI: $10.19074 / 1814-8654-2015-31-153-155$

\section{Контакт: \\ Елена Шнайдер ООО "Сибэкоцентр" 630090, Россия Новосибирск, а/я 547 тел.: + 79137956549 equ001@gmail.com}

\section{Contact:}

Elena Shnayder LLC Sibecocenter P.O. Box 547 , Novosibirsk Russia, 630090 tel.: +79137956549 equ001@gmail.com
Несмотря на то, что чёрный гриср (Aegypius monachus) в Юго-Восточном Алтае в прелелах Республики Алтай встречается практически повсеместно (Карякин и Ар., 2009а; 2009б; Ирисова, Нагибина, 2007; Бахтин и Ар., 2015), впервые гнездование этого вида на Алтае было подтвержцено лишь в 2003 году находкой свежего гнезда, занятого парой грисров в низовьях р. Чаган-Бургазы (Карякин и Ар., 2009а) - ныне этот гнездовой участок уже не сушествует (рис. 1). История заселения грисрами окрестностей Чаган-Узуна берёт начачо с 2002 г., когда здесь была встречена пара птиц с гнездовым поведением, но Аишь в 2006 году здесь было найдено первое жилое гнездо (Карякин и др., 2009а). Позже, в результате обследования ушелья низовий р.

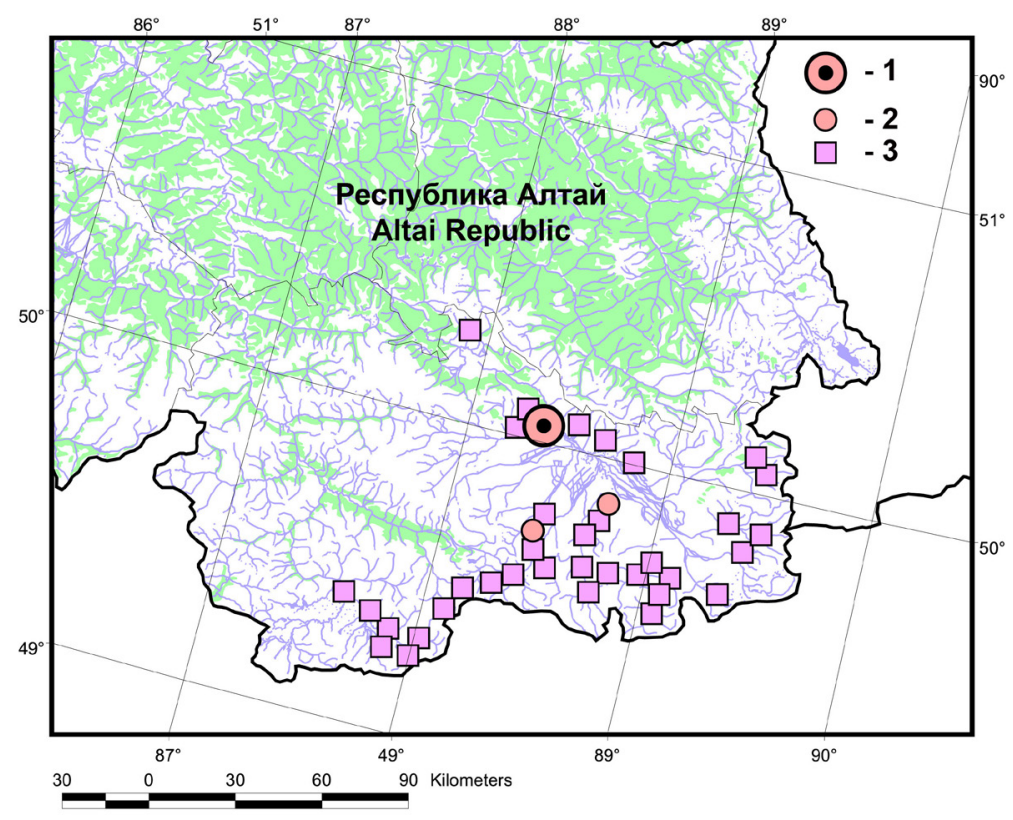

Despite that Cinereous Vultures (Aegypius monachus) are commonly seen in the Altai Republic of Russia (SE part of Altai) (Karyakin et al., 2009a; 2009b; Irisova, Nagibina, 2007; Bachtin et al., 2015), the breeding of the species in the region was confirmed only in 2003 when a nest occupied by a pair of vultures was found in the lower flow of the river Chagan-Burgazii (Karyakin et al., 2009a). Nowadays this breeding territory is abandoned (fig. 1). Later another breeding colony was found in the canyon of river Chagan-Uzun. The history of this colony started in 2002 when the first pair with nesting behavior was observed. However, the first occupied nest was found here only in 2006 (Karyakin et al., 2009a). Lately, throughout searching in the canyon in the lower flow of Chagan-Uzun River provided more nests occupied by at least three breeding pairs of vultures that forms a breeding colony. In 2008 a successful breeding was registered in the two neighboring nests (the spacing between the nests is $1.17 \mathrm{~km}$ ) located on the left side of the canyon. In 2011 the same nests were occupied again, however, only one pair bred successfully (it
Рис. 1. Схема распространения грифа (Aegypius monachus) в Юго-Восточном А^тае: 1 - гнездовая группировка, 2 - попытки гнездования, 3 - места регулярных встреч птиц. Из: Карякин и мр., 2014.

Fig. 1. Distribution of the Cinereous Vulture (Aegypius monachus) in the South- Eastern Altai: 1 - breeding group, 2 - nesting attempts, 3 - regular observations of the birds. From: Karyakin et al., 2014. 


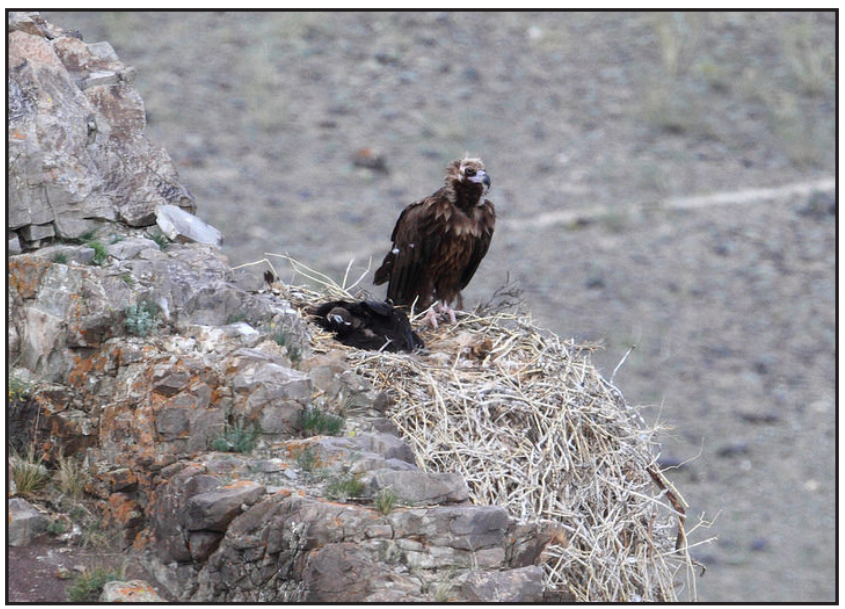

Рис. 2. Взросиый гриср и птенец в гнезде, известном с 2006 года. Июль 2015. Аолина р. Чаган-Узун. Фото Е. Шнайдер.

Fig. 2. An adult Cinereous Vulture and its nestling in the nest known since 2006. July of 2015. Chagan-Uzun River canyon.

Photo by E. Shnayder.
Чаган-Узун было выявлено, что здесь срормироваяась гнездовая группировка минимум из трёх пар грисов. В 2008 г. грисы успешно размножамись на Авух соседних гнездах левого борта ушелья, удалённых Аруг от Аруга на 1,17 км. В 2011 г. вылупление птенцов также было зарегистриро-

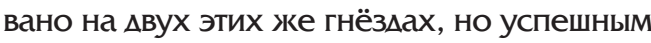
оказалось Аишь одно гнездо, занимавшееся грисом с 2006 г. (во втором гнезде птенец был съелен, вероятно, беркутом Aquila chrysaetus). Третья пара все эти годы абонировала две постройки, периодически полновляя оАну из них, на противоположной стороне ушелья, в 0,95 и 1,16 км от гнёзА грисов, размножавшихся на скалах левого борта ушелья. При проверке 2013 г. именно

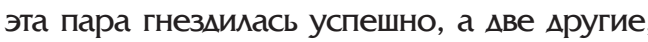
размножавшиеся в 2008-2011 гг., абонироваии гнёзда, возможно и пытаиись размножаться, но успешного размножения не произошло. Интересно отметить, что пара, гнездяшаяся в этом ушелье с 2006 г., построила новое гнездо в 290 м от старого, Аистанцировавшись от соседей на 1,45 и 1,37 км, соответственно. При обследовании ушелья в 2014 г. успешное размножение зарегистри-

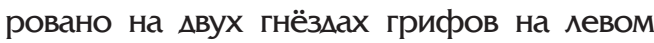
борту ушелья (Карякин и Ар., 2014). В 2015 году размножение в Аолине Чаган-Узуна наблюдаиось только у одной из пар (рис. 2).

В июле 2015 года в ходе экскурсионного маршрута организованного компанией Сибирские экспедиции при подцержке специалистов ООО “Сибэкоцентр" по Аомине р. Кызылшин в бассейне р. ЧаганУзун были обнаружены ешё несколько гнездовых участков чёрного грисра (рис. 3). Новая гнездовая группировка располагается на левом берегу в срелнем течении р. Кызылшин. Всего было найдено четыре гнезда, два из которых оказаиись жилыми (рис. 4). Гнёзда располагаются цепочкой. МежАу соседними was the very first pair observed in the area since 2006). The nest of another pair with a young nestling was ravaged by the Golden Eagle (Aquila chrysaetus).

Through this years the third pair of the $\mathrm{Ci}$ nereous Vultures occupied two nests on the opposite site of the canyon (with the minimal distances from the nests of the neighboring pairs of $0.95 \mathrm{~km}$ and $1.16 \mathrm{~km})$. In 2013 this very pair successfully bred when the other two pairs failed theirs breeding attempts. It is noteworthy that the eldest pair, which occupied the canyon since 2006, built a new nest in 2013. A new nest locates in $290 \mathrm{~m}$ from the old one and thus the spacing between the neighboring pairs increased up to $1.45 \mathrm{~km}$ and $1.37 \mathrm{~km}$. In 2014 successful breeding was observed in the two nests on the left side of the canyon (Karyakin et al., 2014). And in 2015 only the eldest pair reared a fledgling (fig. 2).

A new step in our knowledge on $\mathrm{Ci}$ nereous Vulture spreading in Altai was done at the end of July of 2015 during the volunteer-led expedition organized by Siberian Expedition company in co-working with NGO Siberian Environmental Center (present LLC Sibecocenter) when a new breeding colony was found in the canyon of river Kyziilshin that belongs to the basin of Chagan-Uzun River (fig. 3). The newly found group of nests located on the left side of the canyon in the middle flow of the river Kyziilshin. In total, we found four nest - two of them were empty, but the other two possessed the signs of being used by the vultures in the present year. Checking of the one of those nests yielded us a nice views on a full-fledged nestling (fig. 4). The four newly-found nests located in a row along the river. The distance between the neighboring nests were $0.26 \mathrm{~km}, 0.16 \mathrm{~km}$ and $0.43 \mathrm{~km}$ respectively. The spacing between the occupied nests was $0.43 \mathrm{~km}$. We propose that all four nests belong to two breeding pairs (one pair possess breeding territory with three alternative nests and one with the sole nest), however it is not ruled out that this nests located on breeding territories of three pairs of vultures.

The distance between the newly found colony in the canyon of Kyziilshin and the old one in the canyon of Chagan-Uzun is 4.62 $\mathrm{km}$ average (min $3.91 \mathrm{~km}$, max $5.40 \mathrm{~km}$ ).

It seems to be very promising to explore the upper flow of Kyziilshin river since new breeding territories of the Cinereous Vultures could be found. 


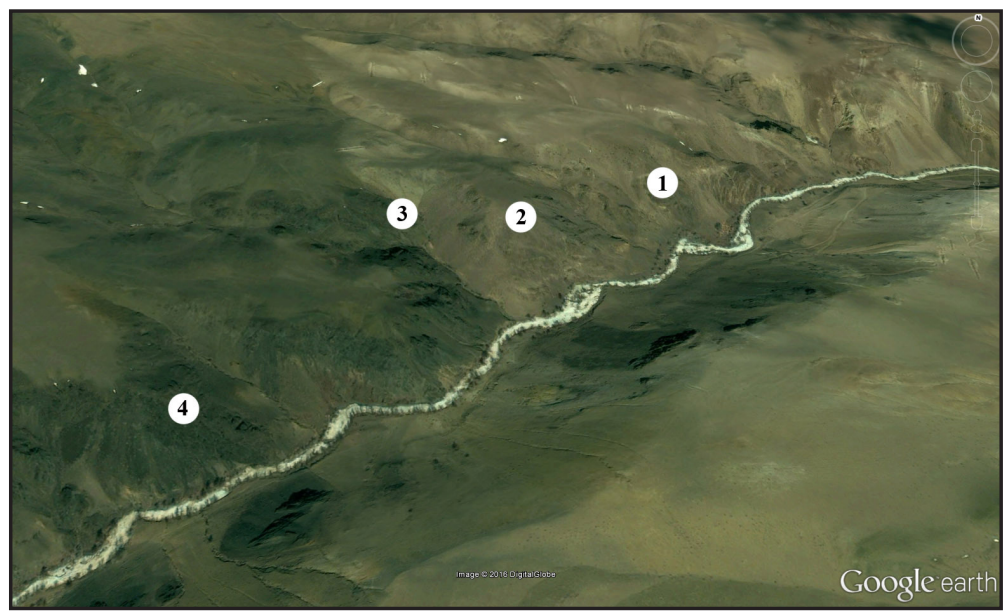

Рис. 3. Распрелеление гнездовых участков грисов в Аолине р. Кызылшин.

Fig. 3. Cinereous Vulture breeding territory distribution in the Kyziilshin River valley.

Рис. 4. Птенец грифа в гнезде, обнаруженном в 2015 г. Июль 2015. Аолина р. Кызылшин. Фото Е. Шнайдер.

Fig. 4. Nestling of the Cinereous Vulture in the nest discovered in 2015. July of 2015. Kyziilshin River valley. Photo by E. Shnayder.

гнёздами расстояние составило соответственно 0,26 км - 0,16 км - 0,43 км. Расстояние между заселёнными гнездами составило 0,43 км. Вероятнее всего, эти гнёзда расположены на двух гнездовых участках чёрного грифра (участок с тремя аиьтернативными гнёздами и участок с одним гнезАОм), хотя не искиючено, что зАесь находятся гнездовые участки трёх пар грисров.

Расстояние от гнёзА новой группировки в долине Кызылшина $\Delta$ гоёзд ранее известной в долине Чаган-Узуна составило в среАнем 4,62 км (мин 3,91 км - макс 5,40 км).

Представляется очень перспективным исследовать верхнее течение р. Кызылшин, поскольку здесь могут быть обнаружены новые гнездовые участки грифов.

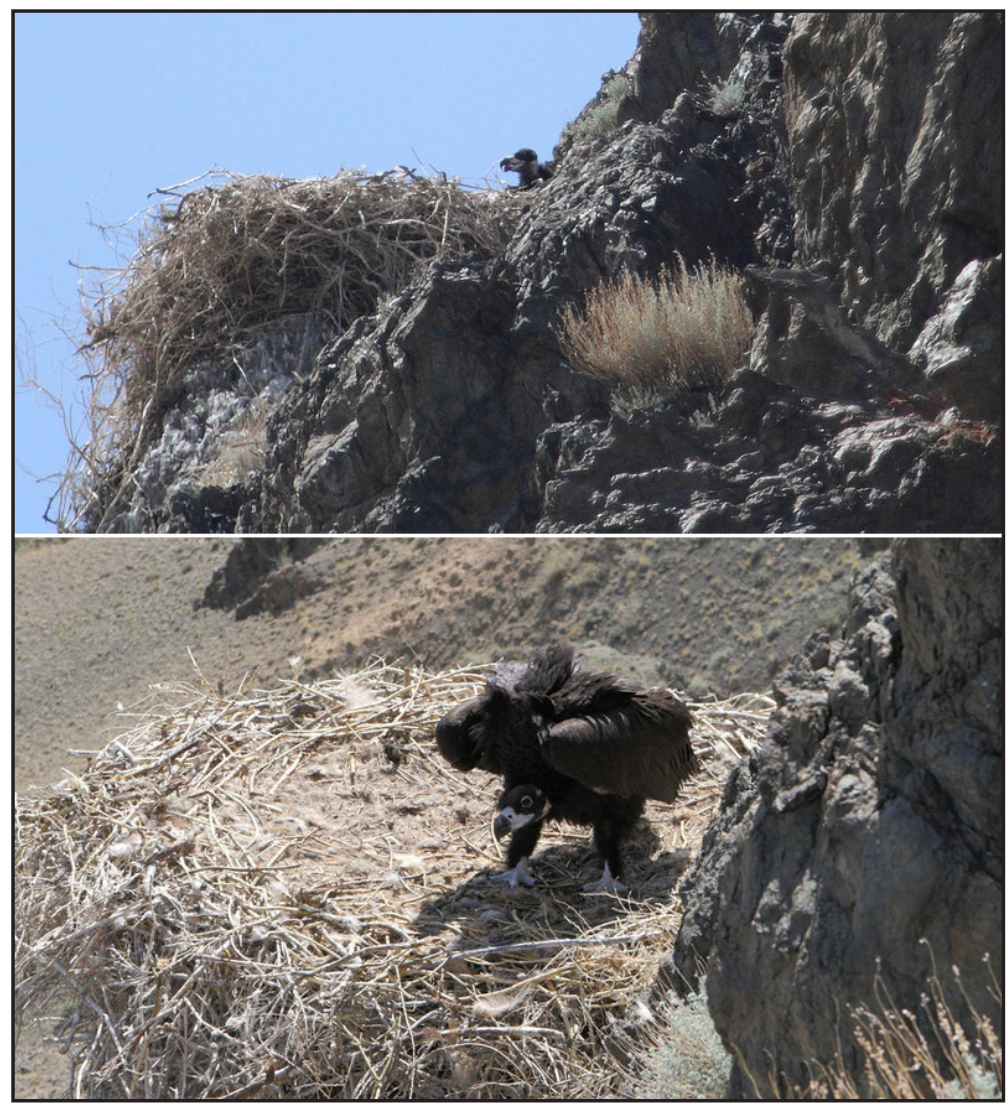

\section{Митература}

Бахтин Р.Ф., Важов С.В., Карякин И.В., Бекмансуров Р.Х., Николенко Э.Г., Барашкова А.Н. Пацаиьшики Аитая (материалы мя Красной книги Республики Алтай). - Исчезаюшие, редкие и слабо изученные виды животных и их отражение в Красной книге Республики Аитай прошлых и будушего изданий (критика и премможения): Материалы российского научного мероприятия, консеренции по подготовке третьего издания Красной книги Республики Алтай (животные). 23-27 марта 2015 года, Горно-Алтайск, 2015. C. 79-84 [Bachtin R.F., Vazhov S.V., Karyakin I.V., Bekmansurov R.H., Nikolenko E.G., Barashkova A.N. Vultures in the Republic of Altai (materials for Red Data Book of the Republic of Altai). - Endangered, rare and poorly-studied species and theirs presence in the past and coming editions of the Red Book of Altai Republic (criticism and suggestions): Proceedings of the Russian scientific conference on preparation of the $3^{\text {rd }}$ edition of the Red Book of Altai Republic (animals). 23-37 March of 2015, Gorno-Altaisk, 2015: 79-84. (in Russian)]. URL: http://rrrcn.ru/wp-content/uploads/2015/08/Bachtin-etal-padalschiki2015.pdf Аата обрашения: 25.12.2015.

Ирисова Н.А., Нагибина Е.Ю. Чёрный гриср - Aegypius monachus (Linnaeus, 1758). - Красная книга Республики Алтай (животные). Горно-Алтайск, 2007. C. 212-216 [Irisova N.L., Nagibina E.Yu. Cinereous Black Vulture - Aegypius monachus (Linnaeus, 1758). - Red Data Book of the Republic of Altai (animals). Gorno-Altaisk, 2007: 212-216. (in Russian)].

Карякин И.В., Бахтин Р.Ф., Важов С.В., Барашкова А.Н., Николенко Э.Г., Шнайдер Е.П., Бекмансуров P.X. Результаты мониторинга гнездовой группировки грисра на Аитае, Россия. - Пернатые хишники и их охрана. 2014. № 28. C. 100-102. doi: 10.19074/1814-86542014-28-100-102 [Karyakin I.V., Bachtin R.F., Vazhov S.V., Barashkova A.N., Nikolenko E.G., Shnayder E.P., Bekmansurov R.H. New Data on the Breeding Group of Cinereous Vulture in Altai Republic, Russia. - Raptors Conservation. 2014. 28: 100-102. doi: 10.19074/1814-86542014-28-100-102]. URL: http://rrrcn.ru/ru/archives/25608 $\triangle$ ата обрашения: 25.12.2015.

Карякин И.В., Коновалов А.И., Грабовский М.А., Николенко Э.Г. Пацамьшики АлтаеСаянского региона. - Пернатые хишники и их охрана. 2009a. № 15. C. 37-65 [Karyakin I.V., Konovalov L.I., Grabovskiy M.A., Nikolenko E.G. Vultures of the Altai-Sayan Region. - Raptors Conservation. 2009a. 15: 37-65]. URL: http://rrrcn.ru/ ru/archives/21062 Аата обрашения: 25.12.2015.

Карякин И.В., Николенко Э.Г., Важов С.В., Бекмансуров Р.Х. Новые Аанные о пацаиьшиках Аитая, Россия. - Пернатые хишники и их охрана. 2009б. № 16. С. 173-376 [Karyakin I.V., Nikolenko E.G., Vazhov S.V., Bekmansurov R.H. New Data on Vultures of the Altai Mountains, Russia. - Raptors Conservation. 2009b. 16: 173376]. URL: http://rrrcn.ru/ru/archives/19529 Аата обрашения: 25.12.2015. 